\title{
Risk Perception of Technological Innovation and Executive Risk Appetite' Impacts on the Science and Technology Insurance Purchase Willingness
}

\author{
Ke-Fan XIE ${ }^{1, a}$ \\ ${ }^{1}$ Management school, Wuhan University of Technology \\ Hubei Wuhan 430070, China \\ axiekefan@163.com
}

\author{
Meng-Ying ZENG ${ }^{2, b^{*}}$ \\ ${ }^{2}$ Management school, Wuhan University of Technology \\ Hubei Wuhan 430070, China \\ bzmy2016@whut.edu.cn
}

\begin{abstract}
Based on survey data of enterprises in Hubei province, structural equation modeling (SEM) was used to explore the relationship between technological innovation activity, technological innovation risk perception, S\&T insurance policy perception, executive risk appetite and science and technology insurance (S\&T insurance) purchase willingness. The result indicates that: (1) there is a positive correlation between technological innovation activity, $S \& T$ insurance policy perception and $S \& T$ insurance purchase willingness. (2) technological innovation risk perception has a positive impact on S\&T insurance purchase willingness, and technological innovation activity also indirectly affects the $S \& T$ insurance purchase willingness through the technological innovation risk perception. (3) executive risk appetite has a negative impact on the S\&T insurance purchase willingness. And executive risk appetite regulates the relationship between technological innovation activity and $S \& T$ insurance purchase willingness.
\end{abstract}

Keywords-S\&T insurance; Insurance Purchase Willingness; SEM; Risk perception; Risk appetite

\section{INTRODUCTION}

Nowadays, the concept of "Creation in China" has been continuously recognized by the society. Governments have put forward relevant policies to promote innovation and entrepreneurship. High-tech enterprises, as one of the main bodies of technological innovation, are springing up and expanding. In order to support small and medium-sized enterprises, the government already issued the Notice on Strengthening and Improving Insurance Services for Hightech

Enterprises as early as 2006, to provide fully risk protection for technological innovation through S\&T insurance.

Though our analysis of S\&T insurance market of high-tech enterprises in Hubei Province, we find the following phenomena and effects: (1) Most of the first batch of S\&T insurance in the pilot project come from the traditional insurance include property insurance and life insurance, with lower technology. (2) The technology of the second batch of S\&T insurance is higher than that of the first batch. But the demand is just reverse, which means that the demand of second batch of S\&T insurance is less than the first batch (see Figure 1). There is a reverse effect: the higher technology the insurances have, the less favored by enterprises. (3) S\&T insurance strongly relies on government subsidy. Then there is inertia effect: when insurance subsidy disappeared, S\&T insurance has no new progress and lack insurance innovation. (4) The governments all over the country regard S\&T insurance as an important method to promote technology innovation, but the enthusiasm of insurance companies and enterprises is not high, which proves an external heat and internal cooling effect. It's found that the current S\&T insurance is still unattractive to high-tech enterprises. What affects the enthusiasm of high-tech enterprises and limits the development of S\&T insurance, it's the purpose of this paper

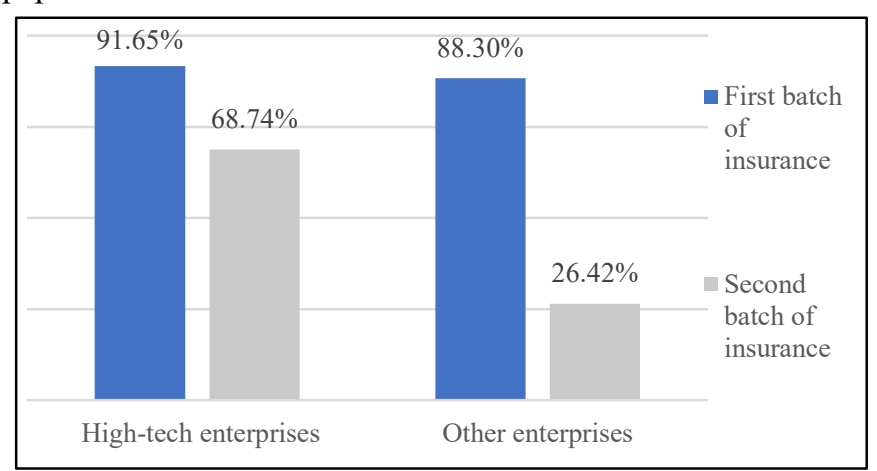

Fig.1 Comparison of demand for S\&T insurance

\section{LITERATURE REVIEW}

Some academicians pay more attention on the specific research of high-tech enterprise risk. CJ Forrest and DL Wesley demonstrate that environmental liability insurance is another tool for managing environmental risk. It can be useful to reduce the risk of pollutants to human health and the environment [1]. Luigi and Giuseppe tend to patent insurance research, they say that the risk of facing elevated legal costs to defend patent rights can affect ex-ante incentives to invest in R\&D [2]. Besides, Scott J. Shackelford notice that firms have increasingly been turning to cyber risk insurance in order to better manage cyber threats and any resulting legal liability from data breaches [3].

Soft Science Research Project of Hubei Province (No. 2016ADC002) 
Owing to S\&T insurance being a new product without any experience, its research still stays in the theoretical stage. Xie [4] and Chen [5] gave the concept of S\&T insurance earlier. Hu [6] found that there are some problems in S\&T insurance, such as low insurance coverage rate, fewer types of S\&T insurance, imperfect supporting services and old-fashioned insurance mechanism. In recent years, the research on S\&T insurance mainly focuses on the practice field. Zhao and Xie ${ }^{[7}$ based on the existing insurance innovation methods, designed a new type of insurance - R\&D Technician Professional Liability insurance, and constructed a rate model.

Study taking enterprises in Hubei Province as the research object, explores the relationship between technological innovation activity, technological innovation risk perception, S\&T insurance policy perception, executive risk appetite and S\&T insurance purchase willingness.

\section{ASSUMPTION AND CONCEPT MODEL}

Technological innovation activity refers to the degree of enterprises carrying out on various activities of technological innovation ${ }^{[8]}$. If the enterprise's technological innovation is highly active, proportion of the researcher and number of invention patents must be high. In other words, key R\& D personnel have large accident risk, for key R\&D equipment have high cost of wear and tear and loss of patent infringement is large, all of whose are likely to be protected by S\&T insurance. Enterprises with high technological innovation activity and rationality should be inclined to purchase S\&T insurance to reduce losses. Therefore, we can put forward the hypothesis that:

H1a: technological innovation activity has a positive impact on $\mathrm{S} \& \mathrm{~T}$ insurance purchase willingness.

Risk perception a feeling of risk and risk characteristics [9]. Denise Doiron found that people's perception of health risks significantly affects their demand for health insurance [10]. Zhou Richter et al. who did an empirical study of long-term care insurance, found that more than 30\% respondents' willingness to buy long-term care insurance changed from "unwillingness" to "willingness" [11]. We can take technological innovation risk perception in factors of S\&T insurance purchase willingness. Thus, the following assumptions are made:

H2a: technological innovation risk perception has a positive impact on S\&T insurance purchase willingness.

technological innovation risk perception is a subjective feeling for the risk of technological innovation. Enterprises with less technological innovation activity will face lower risk of technological innovation. When the manager's risk preference is not considered, the lower the objective risk, the less the demand for S\&T insurance. So, it can be thought that technological innovation risk perception can indirectly affect S\&T insurance purchase willingness through Technological innovation activity. Then, we can propose the following assumptions:
$\mathrm{H} 2 \mathrm{~b}$ : technological innovation risk perception plays an intermediary role in the relationship between technological innovation activity and S\&T insurance purchase willingness.

The government subsidy policy can reduce the premium. The more enterprises understand the S\&T insurance policy, the higher demand for S\&T insurance. Taking rice insurance as an example, Wang and $\mathrm{Yu}$ found that the awareness of policybased insurance has an important impact on farmers' willingness to buy rice insurance [12]. Therefore, we can put forward the hypothesis that:

H3a: S\&T insurance policy perception has a positive impact on S\&T insurance purchase willingness.

According to the viewpoint of economics, people's risk preference can be divided into three types: risk like, risk neutrality and risk aversion. Daniel [13], Simon [14] and Douadia [15] discussed the relationship between willingness to buy flood insurance, medical insurance and crop insurance with risk preference. The result shows that the closer the risk preference is to risk like, the lower probability of buying insurance. Then, we can assume:

H4a: executive risk appetite has a negative impact on S\&T insurance purchase willingness.

When a company has high degree of the technological innovation activity, but unfortunately the manager of the company is totally a risk lover, he probably won't buy insurance because he doesn't feel the risk. That is to say, the direction (positive or negative) of the relationship between technological innovation activity and S\&T insurance purchase willingness is influenced by executive risk appetite. Thus, we can propose the following assumptions:

H4b: executive risk appetite makes regulation effect in the relationship between technological innovation activity and S\&T insurance purchase willingness.

To sum up, the concept model is presented in Figure 2.

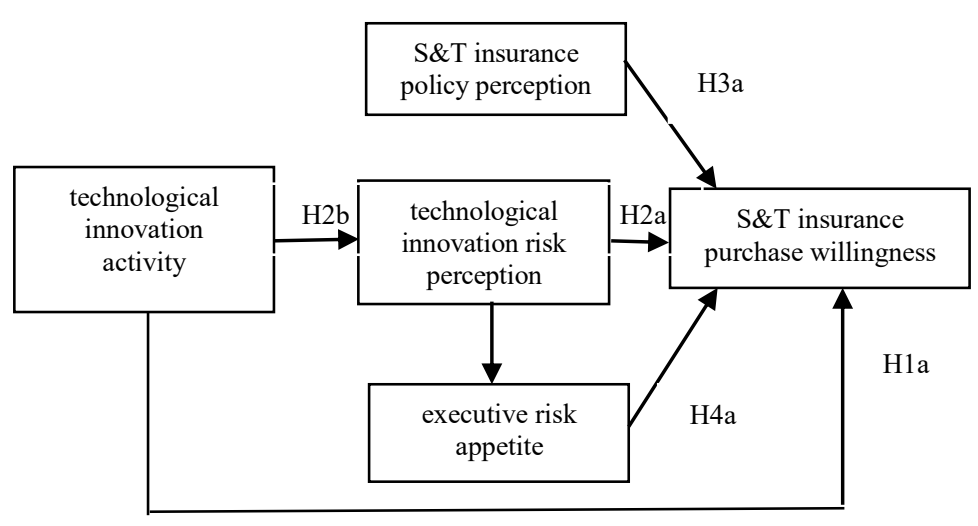

Fig.2 Concept model 


\section{MODEL}

In the procedure of this survey, a total of 180 questionnaires are sent out, 144 are collected and effective questionnaire reached $80 \%$. We use Cronbach's Alpha coefficient testing questionnaire internal consistency. The result is shown in Table 1. Cronbach's Alpha is 0.790 which means that questionnaire has good internal consistency. Next, exploratory factor analysis is used to test the construct validity. The KMO value is 0.714 , the significance level of Bartlett spherical test is less than 0.05 , and the cumulative variance contribution rate is $79.612 \%$. It indicated that $t$ questionnaire has good construct validity. innovation [8]. If the enterprise's technological innovation is highly

TABLE I RELIABILITy AND VALIDITy Test of SCALE

\begin{tabular}{|c|c|c|l|}
\hline $\begin{array}{l}\text { Cronbach's } \\
\text { Alpha }\end{array}$ & KMO & $\begin{array}{c}\text { Bartlett's Test } \\
\text { of Sphericity } \\
\text { Sig. }\end{array}$ & $\begin{array}{l}\text { Cumulative } \\
\text { Variance }\end{array}$ \\
\hline 0.790 & $4^{0.71}$ & 0.000 & $79.612 \%$ \\
\hline
\end{tabular}

The operation results of the SEM show that RMR is 0.092 , less than 0.1, which basically fits the requirements; GFI is 0.943 , greater than 0.9 , reaching the standards; RMSEA is 0.120 , approximate 0.1 , close to the inspection requirements; IFI is 0.854 , more than 0.85 , accepted. From the above indicators, we can see that the model is fit.

TABLE II MODEL FITNESS INDEX

\begin{tabular}{|c|c|c|c|c|}
\hline Model & RMR & GFI & RMSEA & IFI \\
\hline Default model & 0.092 & 0.943 & 0.120 & 0.854 \\
\hline
\end{tabular}

According to the results of the model estimation in Table 3 , the significance of technological innovation activity, technological innovation risk perception, S\&T insurance policy perception for S\&T insurance purchase willingness is $0.045,0.031$ and 0.058 , which is less than or approximate to
0.05 . It shows that the coefficient is significant under the $5 \%$ significance level, and has a significant positive effect on S\&T insurance purchase willingness. Then $\mathrm{H} 1 \mathrm{a}, \mathrm{H} 2 \mathrm{a}$ and $\mathrm{H} 3 \mathrm{a}$ is proved. The significance of executive risk appetite for S\&T insurance purchase willingness is less than 0.001, indicating that under the 5\% significance level, executive risk appetite has a strongly negative impact on the S\&T insurance purchase willingness. Therefore, $\mathrm{H} 4 \mathrm{a}$ is established. Consequently, $\mathrm{H} 1 \mathrm{a}$, $\mathrm{H} 2 \mathrm{a}, \mathrm{H} 3 \mathrm{a}$ and $\mathrm{H} 4 \mathrm{a}$ are all tested.

TABLE III MODEL PATH COEFFICIENTS

\begin{tabular}{|c|c|c|c|c|}
\hline & Path & \multicolumn{2}{|c|}{ path coefficients } & $\mathrm{p}$ \\
\hline $\begin{array}{l}\text { S\&T insurance } \\
\text { purchase } \\
\text { willingness }\end{array}$ & $<---$ & $\begin{array}{l}\text { technological } \\
\text { innovation activity }\end{array}$ & 0.162 & 0.045 \\
\hline $\begin{array}{l}\text { S\&T insurance } \\
\text { purchase } \\
\text { willingness }\end{array}$ & $<---$ & $\begin{array}{ll}\text { technological } \\
\text { innovation } \\
\text { perception }\end{array}$ & 0.166 & 0.031 \\
\hline $\begin{array}{l}\text { S\&T insurance } \\
\text { purchase } \\
\text { willingness }\end{array}$ & $<---$ & $\begin{array}{l}\text { S\&T insurance } \\
\text { policy perception }\end{array}$ & 0.152 & 0.058 \\
\hline $\begin{array}{l}\text { S\&T insurance } \\
\text { purchase } \\
\text { willingness }\end{array}$ & $<---$ & $\begin{array}{ll}\text { executive } & \text { risk } \\
\text { appetite } & \end{array}$ & $-\overline{0}-412$ & $* * *$ \\
\hline
\end{tabular}

Testing the mediating effect of technological innovation risk perception, is done by Bootstrap program in AMOS software. Based on the original sample $(\mathrm{N}=144), 2000$ Bootstrap samples were randomly sampled to calculate the average path coefficient of the mediating effect. If these mean path coefficients do not include 0 under the $95 \%$ confidence interval, the mediating effect is significant [16]. From table 4, we can see that the average path coefficient of technological innovation risk perception is between 0.010 to 0.090 under $95 \%$ confidence interval, not including 0 , which means that the mediating effect is significant. That is to say, technological innovation activity can affect the S\&T insurance purchase willingness through technological innovation risk perception, which supports the hypothesis $\mathrm{H} 2 \mathrm{~b}$.

TABLE IV Bootstrap Analysis of Mediating EfFect Test

\begin{tabular}{|c|c|c|c|c|}
\hline independent variable & mediate variable & dependent variable & $\begin{array}{c}\text { standardization } \\
\text { indirect effect }\end{array}$ & $95 \%$ confidence interval \\
\cline { 3 - 5 } & & & lower limit & upper \\
\hline $\begin{array}{c}\text { technological } \\
\text { innovation activity }\end{array}$ & $\begin{array}{c}\text { technological } \\
\text { innovation risk }\end{array}$ & $\begin{array}{c}\text { S\&T insurance } \\
\text { purchase willingness }\end{array}$ & $0.14 \times 0.17=0.0238$ & 0.010 \\
\hline
\end{tabular}

Testing the regulation effect of executive risk appetite, is done by group linear regression analysis. First, we need to divide executive risk appetite into three group according to their high, middle and low levels - executive risk aversion, executive risk neutrality and executive risk like respectively. Then in every group, do linear regression analysis of technological innovation activity to S\&T insurance purchase willingness, and check whether these regression coefficients are equal. If not all equal, executive risk appetite has a significant moderating effect. The results from table 5 show that the regression coefficient is not equal, proved H4b. At the same time, from the three coefficients, we can find when managers are risk aversion and risk neutrality, the impact of technological innovation activity on S\&T insurance purchase willingness is positive, and when it is executive risk like, the impact of technological innovation activity is obviously negative. This accords to foreword. 
TABLE V Group LinEAR REgRESSION ANALYSIS OF REGULATION EFFECT TEST

\begin{tabular}{|c|c|c|c|c|}
\hline independent variable & Regulating variable & $\begin{array}{c}\text { dependent } \\
\text { variable }\end{array}$ & regression coefficient & Linear regression equation \\
\hline technological & executive risk aversion & S\&T insurance & 0.328 & $\mathrm{Y}=0.328 \mathrm{X} 1+0.245$ \\
\hline innovation & executive risk neutrality & purchase & 0.239 & $\mathrm{Y}=0.239 \mathrm{X} 1-0.404$ \\
\hline activity & executive risk like & willingness & -0.920 & $\mathrm{Y}=-0.920 \mathrm{X} 1-1.659$ \\
\hline
\end{tabular}

\section{CONCLUSION}

The following results can be drawn from the preceding analysis.

Technological innovation activity has a significant positive impact on S\&T insurance purchase willingness. The higher degree of technological innovation activity, the stronger S\&T insurance purchase willingness.

Technological innovation risk perception is positively correlated with the S\&T insurance purchase willingness. In other words, the stronger risk perception of technological innovation and the greater pressure on enterprises, they are more likely to seek the guarantee of S\&T insurance to keep the project going. At the same time, technological innovation risk perception plays an intermediary role between technological innovation activity and S\&T insurance purchase willingness. technological innovation risk has indirectly affected S\&T insurance purchase willingness through technological innovation risk perception.

S\&T insurance policy perception has a significant positive impact on S\&T insurance purchase willingness. The more familiar with S\&T insurance policies, the more believed they are of the role of S\&T insurance in the innovation of enterprises.

The closer the executive risk appetite is to risk aversion, the more he supports S\&T insurance. And when the executive risk appetite is risk like, the inner "fearless" feeling will him get away from S\&T insurance. In addition, executive risk appetite plays a moderating role in the relationship between technological innovation activity and S\&T insurance purchase willingness.

In sum, we believe that external guidance will certainly promote the development of S\&T insurance, but enterprises, is the true one to decide. We find that a lot of companies know little about S\&T and its policies. We need to unite government and insurance companies to frequently give policy interpretation lectures to strengthen the understanding of enterprises on S\&T insurance. Secondly, we should clear that executive risk appetite plays an important role in whether an enterprise purchases insurance. Most risk-loving managers do not support technology insurance. Making compulsory policy of buying S\&T insurance, and following the traditional system of tourism liability insurance and railway passenger accident injury insurance, unconsciously remove the risks of small and medium-sized enterprises. At last, enterprises are the demand of S\&T insurance, insurance company is the supplier. The development of the market is inseparable from the joint efforts of demand and supply. Insurance companies should try hard to resolve the insufficient demand of S\&T insurance. On the one hand, improve the ability of insurer about technology, insurance, policy and management, so that they can keep up with the trend of the times and understand what people need. On the other hand, strengthen cooperation with insurance agency, whose professional technology and special standpoint can help each other reach an agreement.

\section{REFERENCE}

[1] CJ Forrest,DL Wesley. The environmental manager's guide to environmental liability insurance[J]. Environmental Quality Management, 2008,17(3):1-9.

[2] Luigi Buzzacchi, Giuseppe Scellato. Patent litigation insurance and R\&D incentives [J]. International Review of Law and Economics, 2008, 28(04): pp. 272-286.

[3] Scott J. Shackelford. Should your firm invest in cyber risk insurance? [J] Business Horizons, 2012, 55(04): pp. 349-356.

[4] Xie Kefan, Ni Shuguang. Science and Technology Risk and Technology Insurance[J]. Science Management Research, 1995(02): pp. 49-52.

[5] Chen Yulu. Technology Risk and Technology Insurance[J]. China Science and Technology Investment, 2007(1): pp. 68-70.

[6] Hu Xiaoning, Li Qing, Chen Bingzheng. Research on Science and Technology Insurance[J]. Insurance Research, 2009(08): pp. 57-64.

[7] Zhao Wei,Xie Kefan. Innovation Plan and Conception of Science and Technology Insurance Insurance[J]. Science and Technology Management Research. 2011(19): pp. 104-109.

[8] Zhu Shufang. Research on Technology Intermediary Service Strategy Based on Active Science and Technology Innovation[D]. Wuhan: Wuhan University of Technology, 2010.

[9] Wang Feng. Research on Contemporary Risk Perception Theory: Schools, Trends and Controversy[J]. Journal of Beijing University of Aeronautics and Astronautics (Social Science Edition). 2013(03): pp. 18-24.

[10] Denise Doiron, Glenn Jones, Elizabeth Savage. Healthy, wealthy and insured? The role of self-assessed health in the demand for private health insurance[J]. Health economics, 2008, 17(3): pp. 317.

[11] Tian Z R, Browne M J, Gründl H. Don't They Care? Or, Are They Just Unaware? Risk Perception and the Demand for Long-Term Care Insurance[J]. Journal of Risk \& Insurance, 2010, 77(4): pp. 715-747.

[12] Wang Erda, Yu Yang. Analysis of Farmers' Willingness to Pay for Crop Insurance under Multi-guarantee Level[J]. Agricultural Economic Issues. 2010(07): pp. 61-69.

[13] Petrolia D R, Landry C E, Coble K H. Risk Preferences, Risk Perceptions, and Flood Insurance[J]. Land Economics, 2013, 89(2).

[14] Condliffe S, Fiorentino G T. The impact of risk preference on health insurance and health expenditures in the United States[J]. Applied Economics Letters, 2014, 21(9): pp. 613-616.

[15] Bougherara D,Piet L. The Impact of Farmers' Risk Preferences on the Design of an Individual Yield Crop Insurance[J]. Douadia Bougherara, 2017.

[16] Zhao Jingjing, Kong Feng, Wang Yonghui. Relationship between college students' shyness and loneliness: the mediating role of humor style [J]. Chinese Journal of Clinical Psychology. 2012(01): pp. 102-104. 